\title{
Interaction between saliva's adenosine and tick parasitism: effects on feeding and reproduction
}

\author{
Elen Anatriello ${ }^{1 *}$, Carlo José Freire Oliveira ${ }^{2}$, Nathália Baptista Oliveira ${ }^{3}$, Andressa Fisch $^{3}$, Cristiane Maria Milanezi ${ }^{4}$, \\ João Santana da Silva ${ }^{4}$, Isabel Kinney Ferreira de Miranda-Santos ${ }^{3}$ and Beatriz Rossetti Ferreira ${ }^{3}$
}

\begin{abstract}
Background: It has recently been demonstrated that saliva from Rhipicephalus sanguineus ticks contains adenosine (ADO) and prostaglandin E2 (PGE2), two non-protein molecules that have significant immunomodulatory properties. These molecules can inhibit cytokine production by dendritic cells (DCs), while also reducing the expression of CD40 in these cells. However, more studies are needed for a better understanding of their participation in the feeding of ticks in vivo. This work, therefore, evaluated the importance of ADO during tick infestations. Mice were infested with adult ticks (3 couples/mouse), and their skin was collected at the tick-infested site (3rd and 7th day), and mRNA for receptors of ADO was quantified by real-time PCR.

Results: Tick infestation increased by four and two times the expression of the A2b and A3v1 receptors on day 3, respectively, while expression of other ADO receptors was unaltered. In addition, we treated mice ( $n=10 /$ group) daily with 8-(p-Sulfophenyl)theophylline, 8-pSPT, 20 mg/kg, i.p.), a non-selective antagonist of ADO receptors, and evaluated the performance of ticks during infestations. Female ticks fed on 8-pSPT-treated mice presented a reduction in their engorgement, weight and hatching rates of egg masses, and survival times of larvae compared to the same parameters presented by ticks in the control group. To investigate if these 8-pSPT-treated mice presented altered immune responses, we performed three tick infestations and collected their lymph node cells to determine the percentages and activation state of DCs and cytokine production by lymphocytes by flow cytometry (Cytometric Bead Array technique, CBA). Our data showed that 8-pSPT-treated mice presented an increase in the percentage of DCs as well as of their stimulatory and co-stimulatory molecules (CD40, CD80 and MHCII). Regarding production of T cell cytokines, we observed a significant increase in the levels of IL-2 and a significant decrease in IL-10, IL-17, TNF- $a$ and IFN- $\gamma$ cytokines.
\end{abstract}

Conclusions: These results suggest that ADO produced by ticks helps them feed and reproduce and that this effect may be due to modulation of host DCs and T cells.

Keywords: Ticks, Rhipicephalus sanguineus, Saliva, Adenosine, Dendritic cells, T cells

\section{Background}

Over the past few years, the brown dog tick (Rhipicephalus sanguineus) has taken a very important role among the species of ticks in Brazil and worldwide [1-3]. This is due to the direct effects of parasitism and the transmission of disease-causing agents to both dogs and humans [4-8].

\footnotetext{
*Correspondence: elen.anatriello@unifesp.br

'Institute of Science and Technology, Federal University of São Paulo,

UNIFESP, Rua Talim, 330, São José dos Campos, São Paulo 12231-280, Brazil

Full list of author information is available at the end of the article
}

The $R$. sanguineus-host interaction at the skin feeding site is complex. Thus, to succeed during the parasitic phase, these ticks need to overcome the barriers imposed by the host response [9-12]. The first barrier is represented by the hemostatic system, while the second one is imposed by immune cells and molecules of innate and acquired immune response. The hemostasis and immune response appear during the tick attachment phase when the arthropod breaks the physical barrier of the host (skin) and inoculates its saliva to facilitate their access to blood, as well as escape from other host defences systems [11, 13]. 
The number and variety of anti-hemostatic and immunomodulatory components present in tick saliva are so vast that this parasite has been considered a "professional pharmacologist" and has been studied as a source of numerous therapeutic targets [11, 14-16]. The antihemostatic and immunomodulatory activities of tick saliva $[11-13,17]$ include the modulation of vasodilation $[17,18]$, inhibition of platelet aggregation [19], reduction of T lymphocyte proliferation and function [20, 21], suppression of the activity and production of cytokines and chemokines [21-23], inhibition of maturation and function of macrophages [21, 23, 24], dendritic cells (DCs) [25-29], neutrophils [30], mast cells and natural killer (NK) cells [24], and containment of mediators essential for rash and pain induction [31].

Given the induction of innate and acquired immune response is triggered mainly by DCs, since they are specialised in activating naïve lymphocytes and initiating primary immune responses [32], our group has investigated, whether the modulation of immune response mediated by tick infestation is dependent on these cells. We have shown that the saliva of $R$. sanguineus ticks inhibits DCs differentiation, reduces the expression of stimulatory and co-stimulatory molecules like CD40, CD80 and CD86, and modulate DCs cytokine production [26-28]. Moreover, we showed that its effect, at least in vitro, is dependent in part on adenosine (ADO) and prostaglandin E2 (PGE2), two non-protein molecules contained in the saliva that have multiple immunomodulatory properties [29].

$\mathrm{ADO}$ is an endogenous purine nucleoside that modulates a wide variety of functions in several cells of the immune system, including DCs, T and B cells, within others [33-36]. In order to exert its activity, ADO binds specifically to a family of four G-protein receptors, named A1, A2a, A2b, and A3 receptors. Interestingly, ADO exercises its anti-inflammatory/ immunosuppressive effects by binding to the A2a and A2b receptors, whereas the binding to the $\mathrm{A} 1$ and $\mathrm{A} 3$ receptors results in pro-inflammatory actions [37-39].

Importantly, ADO has been identified in salivary glands of other classes of hematophagous arthropods, notably, the sand flies Phlebotomus argentipes and
Phlebotomus duboscqui [40, 41]. In addition, it has been shown that ADO and AMP in Phlebotomus papatasi saliva mediate the exacerbating effects of Leishmania infection by promoting a tolerogenic profile in DCs and by differentiating inducible $\mathrm{T}$ regulatory cells in the inflammatory site through an A2a receptor mechanism [42].

The present study evaluated, for the first time, the in vivo participation of ADO during infestation of mice by $R$. sanguineus ticks. We studied the expression of ADO receptors, the feeding and reproductive parameters of ticks, and the immune response of tick-infested mice treated or not with a non-selective antagonist of ADO receptors. Moreover, we tested if knockout (KO) mice for $\mathrm{A} 2 \mathrm{a}$ receptors were enhanced in their resistance to ticks. The study of the role of ADO in a tick infestation can contribute to a better understanding of the tick-host interface.

\section{Methods}

Colony of ticks and infestation

Rhipicephalus sanguineus ticks were laboratory-reared as previously described [43]. For tick infestation experiments, BALB/c mice (10 animals per group) were infested with three pairs of adult $R$. sanguineus ticks restricted in plastic feeding chambers fixed to their backs, as previously described [21]. BALB/c mice were three times tick-infested (7-15 days/per infestation), with an interval of 30 days between each infestation, and animals were treated daily with a non-selective antagonist of ADO receptors (8-pSPT, $20 \mathrm{mg} / \mathrm{kg}$ i.p.) or with saline (see Table 1 for the experimental design). During the successive infestations (always on different skin sites), the ticks were evaluated for their biological parameters, i.e. the average weight of the engorged females, egg mass weight, reproductive index, larva hatching rate and larva survival period. In all the experiments of infestation we added a group of Sham animals, a control group consisted of mice that had the chamber fixed to their backs, but had no ticks released. This group was relevant to avoid misinterpretations due to the effect of the glue used to fix the chambers.

Table 1 Experimental design

\begin{tabular}{|c|c|c|c|c|}
\hline \multirow[t]{2}{*}{ Analysed parameters } & \multicolumn{4}{|l|}{ Groups } \\
\hline & $\begin{array}{l}\text { First infestation on } \\
\text { WT mice }\end{array}$ & $\begin{array}{l}\text { First and second infestation } \\
+8 \text {-pSPT-treated WT mice }\end{array}$ & $\begin{array}{l}\text { Third infestation +8-pSPT- } \\
\text { treated WT mice }\end{array}$ & $\begin{array}{l}\text { First and second infestation } \\
\text { on } \mathrm{A} 2 \mathrm{a} \mathrm{R}-/- \text { mice }\end{array}$ \\
\hline Expression of the ADO and PGE2 receptors & - & - & - & - \\
\hline Performance of ticks & - & + & - & + \\
\hline $\begin{array}{l}\text { Expression of stimulatory and } \\
\text { co-stimulatory molecules }\end{array}$ & - & - & + & - \\
\hline Cytokine production & - & - & + & - \\
\hline
\end{tabular}

+, Done; -, Not done; 8-pSPT, non-specific antagonist for ADO receptors 


\section{Mice}

$\mathrm{BALB} / \mathrm{c}$ and $\mathrm{KO}$ mice for A2a receptors (A2Ar-/- mice on a BALB/c background) [44] 6-week USA) and bred/ maintained at the Central Animal Facility of the School of Medicine-USP, Ribeirão Preto. These animals were housed in temperature-controlled rooms $\left(22-25^{\circ} \mathrm{C}\right)$ and received water and food ad libitum.

\section{Real-time polymerase chain reaction for ADO receptors ( $A 1, A 2 a, A 2 b$ and $A 3 v 1$ and $A 3 v 2)$ and $P G E 2$ receptors (EP1, EP2, EP3 and EP4)}

Skin samples from mice one-time tick-infested ( 3 and 7 days tick-infested) or non-infested (Sham animals; control group) were collected from the area where the ticks were attached or the corresponding site on the Sham mice and placed into a metal block (Biospec, Bartlesville, OK, EUA), added to liquid nitrogen and pulverized using a hammer.

The total RNA was extracted using the TRIzol reagent (Invitrogen, Carlsbad, CA, USA) and the SV Total RNA Isolation System Kit (Promega, Madison, WI, USA), according to the manufacturer's instructions. Complementary DNA was synthesised using ImProm-II TM Reverse Transcription System (Promega, Madison, WI, USA). SYBR Green Mixbased quantitative real-time PCR assays were performed using the StepOnePlus Real-Time PCR System (Applied Biosystems, Singapore, Malaysia). The mean threshold cycle (Ct) values of measurements were used to calculate the expression of the target gene, which was normalised to the housekeeping gene $\beta$-actin, using the $2^{-\Delta \Delta C t}$ formula.

The primers were the following: A1: $5^{\prime}-\mathrm{GTT}$ GCC AGC AGT TTT GCC CAC TC-3', 5'-AGC CCG CAG GGG CTC ATA TCA-3', A2a: 5'-TTC TTC GCC TGC TTT GTC CT-3', 5' -ATA CCC GTC ACC AAG CCA TT-3', A2b: 5'-CTG CTC ATA ATG CTG GTG ATC T-3', 5'-ATC AGT TCC ATG CGC TGA-3', A3v1 (isoform 1): 5' -CTA CGC CTG CAA AAT AAA AAA G-3', 5'-GTC CAA AGA ATC TGA GGT CTG A-3', A3v2: isoform 2): 5' -CAA AAG CAT CAG TAG AAA CCC A-3', 5' -ACC GCA CTT CAA ATC CTT GCC-3', $\beta$-actin: 5'-CCT TCC TTC TTG GGT ATG GAA T-3', 5'-TGG CAT AGA GGT CTT TAC GGA T-3', EP1: 5' GTT GCC AGC AGT TTT GCC CAC TC-3', 5'-AGC CCG CAG GGG CTC ATA TCA-3', EP2: 5'-GGC CGG AAG GGA GCT CTG GA-3', 5' -CGG AGG GTC TGA TGG CCC CA-3', EP3: 5'-GCT ATC CCG CAG CTG AGC CG-3', 5'-GGG AAA GGC CAC GGA CAC GG3', EP4: 5'-GGT CCT GAA CAT CTG AGG CCT GAG C-3', 5' -CGC GTT GAC TCC GGG GAT GGA-3'.

\section{Evaluation of biological and reproductive parameters of ticks feeding on mice treated or not with an ADO receptor antagonist or $\mathrm{KO}$ mice for $\mathrm{A} 2 \mathrm{a}$ receptors} To investigate the in vivo participation of ADO during an infestation of mice by $R$. sanguineus ticks, we treated mice with an antagonist of ADO receptors and infested mice deficient for A2a receptors.

For the assay with the ADO receptors antagonist, $\mathrm{BALB} / \mathrm{c}$ mice were infested three times (interval of 30 days between infestations) with three couples of $R$. sanguineus adult ticks and treated daily with a nonselective antagonist of ADO receptors (8-pSPT, $20 \mathrm{mg} /$ $\mathrm{kg} / 100 \mu \mathrm{l}$ i.p.) or saline ( $n=10$ per group) throughout all infestations (9-13 days/infestation). After tick detachment, the biological and reproductive parameters were measured (average weight of the engorged females, egg mass weight, reproductive index, larva hatching rate and larva survival period). The reproductive index was calculated by dividing the egg mass weight (g)/female engorged weight $(\mathrm{g}) \times 100$. The biological and reproductive parameters of the ticks were only measured on the first and the second infestations since the mice infested three times were killed and used to evaluate DCs activation and cytokine production on the third or seventh day of the third infestation.

To test if $\mathrm{KO}$ mice for A2a receptors (A2aR-/-) would present enhanced resistance to ticks, BALB/c A2aR-/mice and wild-type mice (WT) ( $n=10$ per group) were one-time tick-infested with three couples of $R$. sanguineus adult ticks and evaluated for similar biological and reproductive parameters as described above, added to the determination of the engorged female number detached for each group.

\section{Evaluation of DCs activation and cytokine production after treatment with ADO receptor antagonist in mice infested with ticks}

$\mathrm{BALB} / \mathrm{c}$ mice were infested three times (interval of 30 days between the infestations) with three pairs of $R$. sanguineus ticks. These animals were treated daily with 8-pSPT $(20 \mathrm{mg} / \mathrm{kg}$, i.p.) or saline. Mice were killed on the third and seventh day (3D and 7D) of the third infestation and cells from lymph nodes draining the infestation site (axillary and brachial lymph nodes) were cultured with and without Concanavalin A (Con-A; $2 \mathrm{mg} / \mathrm{mL}$ ). After $24 \mathrm{~h}$ of culture at $37{ }^{\circ} \mathrm{C}$ in $5 \% \mathrm{CO}_{2}$, the supernatants were collected and stored at $-80{ }^{\circ} \mathrm{C}$ until use. To study DCs activation, the cells were labelled with monoclonal antibodies conjugated with fluorochromes against CD11c, CD80, CD86, CD40 and MHCII (I-A/I-E) molecules (Biolegend, San Diego, CA, USA). Briefly, after cells were fixed in PBS plus $2 \%$ formaldehyde, they were incubated for $30 \mathrm{~min}$ with the specific antibodies. Subsequently, the cells were washed with a permeabilization buffer (PBS added fetal bovine serum 1\%, sodium azide $0.1 \%$ and saponin $0.2 \%$ ), followed by washing with PBS and re-suspension in $100 \mu$ l of PBS. Fluorescence was measured on an FACSCanto Reading II (Becton Dickinson, San Jose CA, USA) obtained in 100,000 events/sample and 
analysis were performed using the Flow Jo software (TreeStar, Ashland, OR, USA). DCs were firstly gated based on their characteristic of size (FSC) and granularity (SSC), and secondly for the expression of CD11c, MHCII, CD40, CD80 and CD86 markers.

The cytokine levels in the supernatants were determined by Cytometric Bead Array (CBA technique) using the mouse Th1/Th2/Th17 CBA Kit following the manufacturer's instructions (BD Biosciences, San Jose, CA, USA). Cytokine analysis was performed on the $\mathrm{BD}^{\mathrm{mm}}$ FACSCanto Reading II (BD Biosciences). All the quantitative analysis was done using FCAP Array ${ }^{\mathrm{max}}$ Software (BD Biosciences).

\section{Statistical analysis}

Data were analysed using GraphPad PRISM 5.0 software (GraphPad Software Inc., La Jolla, CA) and presented as mean \pm SEM. Comparisons between animal groups were performed using unpaired Student $t$-test, or the Mann-Whitney test for samples with nonparametric distributions.

\section{Results}

Tick infestation increased mRNA expression of the ADO receptors $A 2 b$ and $A 3 v 1$ in mouse skin

The results showed that the tick infestation (just one infestation) induced a four and a two-fold increase in the mRNA expression of $\mathrm{A} 2 \mathrm{~b}$ and $\mathrm{A} 3 \mathrm{v} 1$ receptors, respectively on day 3 , while no other ADO receptors were significantly altered when compared with the Sham control; control group (Fig. 1). In addition, on the 7th day of infestation, both groups responded similarly. We also investigated the expression of mRNA for $\mathrm{PGE}_{2}$ receptors (EP2, EP3 and EP4), and the results showed that the skin of mice infested with ticks presented unchanged mRNA expression for $\mathrm{PGE}_{2}$ receptors at the time points analysed (Table 2).

\section{Treatment of mice with an ADO receptor antagonist} reduced tick-feeding performance on the first infestation We treated mice daily with 8-pSPT, a non-selective antagonist of ADO receptors, during the first and second infestation to evaluate the performance of ticks during an infestation when ADO signalling is blocked.
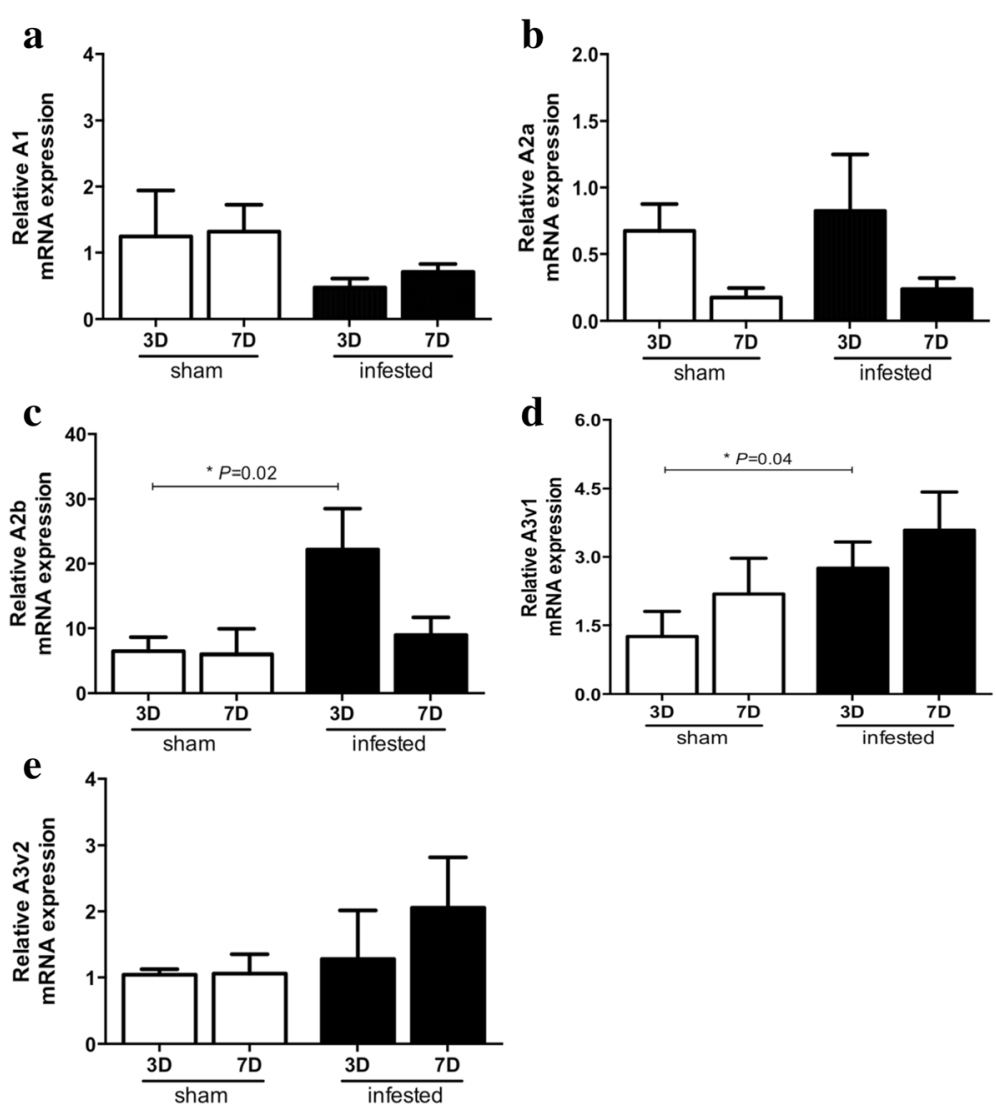

Fig. 1 The relative mRNA expression of the ADO receptors in mice skin. Skin samples from one-time tick-infested and sham BALB/c mice; control group (5 to 9/group) were collected on the 3rd and 7th day (3D and 7D) after infestation and processed for assessment of gene expression of receptors for adenosine by real-time PCR. Data are presented as mean values \pm SEM of relative expression of A1 (a), A2a (b), A2b (c), A3v1 (d) and A3v2 (e) mRNA for a target gene normalized for RNA expression of the housekeeping $\beta$-actin gene 
Table 2 The relative mRNA expression of the PGE2 receptors in one-time tick-infested and non-infested (sham group; control group) mice skin

\begin{tabular}{llll}
\hline & \multicolumn{2}{l}{ Expression of the target gene normalised to the housekeeping gene $\beta$-actin using the $2^{-\Delta \Delta C t}$ formula } \\
\cline { 2 - 4 } Groups & EP2 & EP3 & EP4 \\
\hline 3D control & $1.543 \pm 1.175$ & $0.843 \pm 0.475$ & $1.001 \pm 0.042$ \\
3D infested & $0.395 \pm 0.195$ & $0.634 \pm 0.463$ & $0.432 \pm 0.186$ \\
$P$-value & 0.29 & 0.78 & 0.09 \\
7D control & $1.054 \pm 0.219$ & $1.003 \pm 0.055$ & $1.623 \pm 1.103$ \\
7D infested & $0.693 \pm 0.183$ & $0.749 \pm 0.281$ & $1.766 \pm 0,665$ \\
$P$-value & 0.26 & 0.48 & 0.91 \\
\hline
\end{tabular}

$N=3-5 /$ group; $\mathrm{D}$, days

In the first infestation, we observed that ticks fed on 8-pSPT-treated mice presented a significant reduction in several biological parameters analysed; i.e. engorgement weight of females, egg mass, hatching rate and the larva survival period $(P<0.05)$. The engorgement weight of females showed an average of $0.155 \mathrm{~g}$ for ticks fed on the control mice, with a variation ranging from 0.115 to $0.186 \mathrm{~g}$, while for the 8-pSPT-treated mice the mean weight was $0.115 \mathrm{~g}$, with a range from 0.017 to $0.156 \mathrm{~g}$ (Mann-Whitney $U$-test: $U_{(8)}=12, P=0.03$, Fig. 2a). For the egg mass, the mean value was $0.084 \mathrm{~g}$ (ranging from 0.053 to $0.104 \mathrm{~g}$ ) and $0.058 \mathrm{~g}$ (ranging from 0 to $0.086 \mathrm{~g}$ )

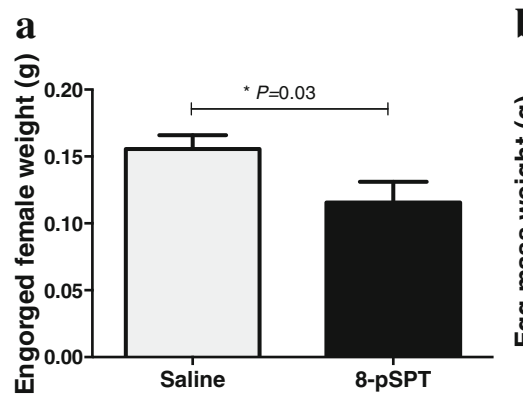

b

c
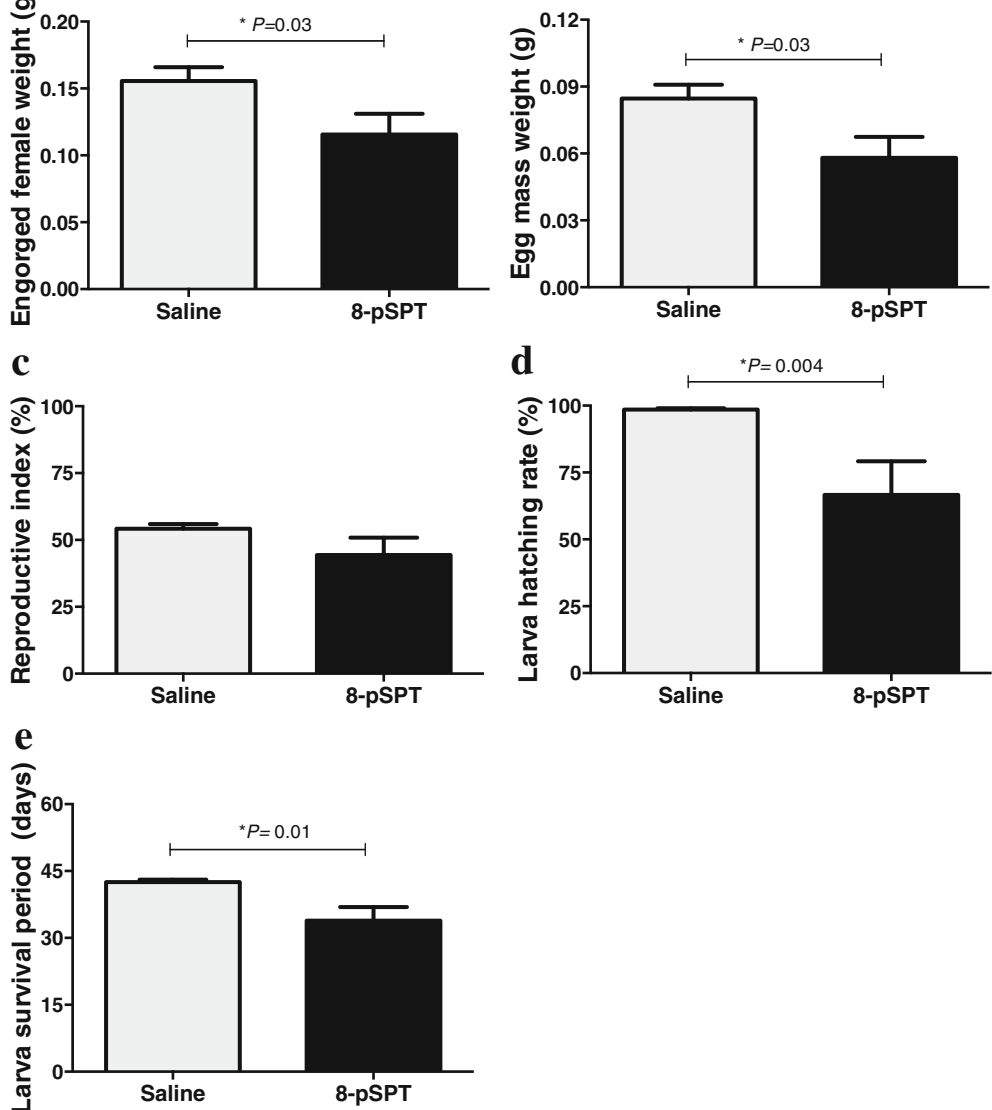

Fig. 2 Performance of ticks feeding on mice treated with an ADO receptor antagonist. BALB/c mice ( $n=10 /$ group) were infested with three couples of adult ticks and treated daily with a non-selective antagonist of ADO (8-pSPT, $20 \mathrm{mg} / \mathrm{kg}$ i.p.) or saline. After tick detachment, female ticks were weighed (a) and placed in a chamber for oviposition. The egg mass weight (b) was measured 15 days after the engorged female tick detachment and after the reproductive index (c) larva hatching rate (d) and larva survival period (e) was calculated. Data are presented as mean values \pm SEM from two independent experiments 
for ticks fed on control and 8-pSPT-treated mice, respectively ( $t$-test: $t_{(8)}=2.343, P=0.03$, Fig. $\left.2 \mathrm{~b}\right)$. Analysis of the hatching rate and the larva survival period, revealed a reduction of $32 \%$ and $20 \%$ respectively, between the treated and untreated mice (Mann-Whitney U-test: $U_{(8)}=10, P=0.004$; Fig. 2d and Mann-Whitney $U$-test: $U_{(8)}=8, P=0.01$, Fig. 2e). The only parameter that was not changed between the groups was the capacity of female ticks to transform the ingested blood into eggs (Mann-Whitney $U$-test: $U_{(8)}=16, P=0.10$; i.e. reproductive index; Fig. 2c).

During the second infestation, the unique tick parameter that changed between the mice treated with the antagonist (8-pSPT) and the controls was the larva survival period, which was reduced by $12 \%$ on the antagonist-treated group (Table 3).

So far, our results suggest that the blockade of ADO receptors particularly affected the performance of ticks during the first infestation (Table 3).

\section{Deficiency of the A2a receptor in mice did not impair the biological and reproductive parameters of ticks during infestation}

Tick-infested A2aR-/- mice did not present change in the number of engorged females, the weight of the engorged females, egg mass weight, reproductive index and larva hatching rate (Table 4).

\section{Treatment of tick-infested mice with an ADO receptors antagonist modulated DCs and altered lymph node cytokine production}

To investigate whether treatment with 8-pSPT alters the immune response of mice infested with ticks, we performed one more infestation (third infestation) and collected the draining lymph nodes to determine the expression of stimulatory and co-stimulatory molecules CD40, CD86, CD80 and MHCII on DCs (CD11c ${ }^{+}$cells) as also the production of cytokines.
Our data showed that on the third day of infestation, the 8-pSPT-treated group presented a significant increase in the percentage of DCs $\left(\mathrm{CD} 11 \mathrm{c}^{+}\right)$(t-test: $\left.t_{(8)}=3.576, P=0.002\right)$ and $\mathrm{CD} 11 \mathrm{c}^{+} \mathrm{CD} 40^{+}$cells (t-test: $\left.t_{(2.973)}=2.973, P=0.01\right)$ compared to the controls, however the same was not detected on the seventh day (Fig. 3a-d). Furthermore, the treatment with 8-pSPT induced a significant increase in the percentage of CD11c ${ }^{+} \mathrm{MHCII}^{+}$cells in the both days evaluated (Fig. 3c), while an enhanced frequency of $\mathrm{CD} 11 \mathrm{c}^{+} \mathrm{CD} 80^{+}$cells was observed only on the seventh day (Fig. 3e). Concerning the percentage of $\mathrm{CD} 11 \mathrm{c}^{+} \mathrm{CD} 86^{+}$cells, no significant differences between the 8-pSPT-treated or control group were observed (data not shown).

To investigate the effect of the 8-pSPT treatment on the cytokine production by cells of the lymph nodes of tick-infested mice, we stimulated the cell cultures with Con-A and the Th1, Th2 and Th17 cytokines profiles in the supernatant were measured by CBA (Fig. 4). On the third day of the third infestation, the production of IL-2 increased by 10 times for the cells of 8-pSPT-treated mice compared the control group (Mann-Whitney $U$ test: $\left.U_{(6)}=1, P=0.004\right)$ (Fig. 4a). Additionally, on the same third day, the treated group showed a significant decrease in the production of IL-17 (Mann-Whitney $U$-test: $\left.U_{(6)}=0, P=0.002\right)$, TNF- $\alpha\left(\mathrm{t}\right.$-test: $\left.t_{(6)}=2.810, P=0.01\right)$, IFN- $\gamma$ (Mann-Whitney $U$-test: $U_{(6)}=4, P=0.02$ ) and IL10 compared to the controls (Mann-Whitney $U$-test: $U_{(6)}=0, P=0.002$ ) (Fig. $4 \mathrm{~d}-\mathrm{g}$ ). No differences in the production of IL- 4 and IL- 6 were detected in the supernatants of cells from both groups (Fig. 4b, c).

\section{Discussion}

It is known that the expression of ADO and PGE2 receptors is regulated during physiological and pathological stress [45] when both are upregulated to suppress cell activity. As previously described, $R$. sanguineus ticks produce high concentrations of ADO and PGE2, which accumulate in tick saliva and are inoculated into the

Table 3 Biological parameters analysed on tick-infested mice treated with 8-pSPT or saline

\begin{tabular}{|c|c|c|c|c|c|}
\hline Groups & $\begin{array}{l}\text { Engorged female weight (g) } \\
\pm \text { SEM }\end{array}$ & $\begin{array}{l}\text { Egg mass weight (g) } \\
\pm \text { SEM }\end{array}$ & $\begin{array}{l}\text { Reproductive index } \\
\pm \text { SEM }\end{array}$ & $\begin{array}{l}\text { Larva hatching rate (\%) } \\
\pm \text { SEM }\end{array}$ & $\begin{array}{l}\text { Larva survival period (days) } \\
\pm \text { SEM }\end{array}$ \\
\hline \multicolumn{6}{|c|}{ First infestation } \\
\hline Saline & $0.155 \pm 0.01$ & $0.084 \pm 0.01$ & $54.19 \pm 1.67$ & $88.56 \pm 0.44$ & $42.50 \pm 0.59$ \\
\hline 8-pSPT & $0.115 \pm 0.01$ & $0.058 \pm 0.01$ & $44.19 \pm 6.46$ & $66.63 \pm 12.58$ & $33.86 \pm 3.07$ \\
\hline$P$-value & $0.04^{*}$ & $0.03^{*}$ & 0.16 & $0.01^{*}$ & $0.01^{*}$ \\
\hline \multicolumn{6}{|c|}{ Second infestation } \\
\hline Saline & $0.131 \pm 0.01$ & $0.078 \pm 0.01$ & $58.96 \pm 2.08$ & $83.57 \pm 3.95$ & $45.71 \pm 1.59$ \\
\hline 8-pSPT & $0.105 \pm 0.01$ & $0.055 \pm 0.01$ & $46.36 \pm 7.35$ & $77.13 \pm 11.99$ & $40.14 \pm 1.66$ \\
\hline$P$-value & 0.18 & 0.12 & 0.14 & 0.24 & $0.03^{*}$ \\
\hline
\end{tabular}

${ }^{*} P<0.05$ comparing the 8-pSPT-treated group with the control group (saline)

$N=10$ /group; 8-pSPT, non-specific antagonist for ADO receptors 
Table 4 Biological parameters analysed on WT and A2aR-/- tick-infested mice

\begin{tabular}{llllll}
\hline Groups & $\begin{array}{l}\text { Engorged } \\
\text { female (\%) } \pm \text { SEM }\end{array}$ & $\begin{array}{l}\text { Engorged female } \\
\text { weight }(g) \pm \text { SEM }\end{array}$ & $\begin{array}{l}\text { Egg mass } \\
\text { weight }(g) \pm \text { SEM }\end{array}$ & $\begin{array}{l}\text { Reproductive } \\
\text { index } \pm \text { SEM }\end{array}$ & $\begin{array}{l}\text { Larva hatching } \\
\text { rate }(\%) \pm \text { SEM }\end{array}$ \\
\hline First infestation & & & & & \\
WT & $33 \pm 7.02$ & $0.105 \pm 0.02$ & $0.69 \pm 0.01$ & $56 \pm 3.85$ & $61 \pm 45$ \\
A2aR- - & $53 \pm 12.37$ & $0.113 \pm 0.01$ & $0.69 \pm 0.01$ & $53 \pm 2.86$ & $88 \pm 25$ \\
$P$-value & 0.11 & 0.74 & 0.98 & 0.65 & 0.06 \\
\hline
\end{tabular}

$N=10 /$ group

host skin during feeding [29]. This was also reported for other tick species, such as Amblyomma americanum for ADO [46] and Dermacentor variabilis for PGE2 [47]. The latter showed that ticks use salivary PGE2 to impair macrophages to produce pro-inflammatory mediators and recruit fibroblasts to the feeding site, consequently inhibiting wound healing [47]. Therefore, a better understanding of the dynamic of expression of ADO and PGE2 receptors in the host skin during an infestation can help to unravel the role of these molecules in the success of the tick to achieve a good blood meal.

Here, we demonstrate that there is a significant increase in gene expression for the $\mathrm{A} 2 \mathrm{~b}$ and $\mathrm{A} 3 \mathrm{v} 1$ receptors on the third day of a tick infestation on BALB/C mice. Previously, others have demonstrated that the A2b and $\mathrm{A} 3$ receptors are upregulated in inflammation, stress or injury and that blocking them with the use of selective antagonists can be used as a treatment for inflammatory diseases, such as Parkinson's disease, ischemia and cancer [36, 48-52]. Our study also showed that on the seventh day of infestation, the A2b and A3v1 receptors expression returned to control values. This may have happened because of the large volume of tick saliva already released into the host skin, which contains a variety of other immunosuppressive molecules that can modulate the inflammation independently from the ADO signalling pathway $[11,13]$.

In regard to the expression of mRNA for $\mathrm{PGE}_{2}$ receptors (EP2, EP3 and EP4), these were unchanged during the tick infestation at the time points analysed (data not shown), while EP1 receptor was not detected in the skin of mice, regardless they were infested or not with ticks (data not shown). This latter observation corroborates other studies that show that, unlike other PGE2 receptors, the EP1 receptor is not expressed in the skin of mice [53].

Concerning that tick infestation modulates the expression of mRNA for $\mathrm{A} 2 \mathrm{~b}$ and $\mathrm{A} 3 \mathrm{v} 1$ receptors in mice, we treated them daily with a non-selective antagonist of ADO receptors (8-pSPT) during the first and second infestation to evaluate the importance of ADO signalling pathway in the performance of ticks. Data indicate that the blockade of $\mathrm{ADO}$ receptors induces a significant reduction in the biological and reproductive parameters of ticks during the first infestation on mice, whereas during the second infestation this did not occur. A possible explanation can be that ticks produce different components within the time-course of feeding $[54,55]$. Thus, additional regulatory molecules can be introduced into the host by the 7th day of infestation.

Although not having found a difference in the expression of $\mathrm{A} 2 \mathrm{aR}$ on tick infested mice and knowing that ADO from Phlebotomus papatasi can suppress the immune response via $\mathrm{A} 2 \mathrm{aR}$ [42], we tested if the lack of this receptor in mice (A2aR-/-) could reduce tick infestation performance. Our results indicated that this deficiency was not enough to compromise tick-feeding success, suggesting that other receptors (i.e. A2bR and A3v1R) are involved in the immunosuppression. This possibility has yet to be tested.

Our results indicate that ADO of tick saliva possibly plays an important role in suppressing host immune/inflammatory mechanisms, at least in the initial phase of tick feeding. This can happen, since other studies show that ADO can reduce the expression of adhesion molecules in endothelial cells, resulting in a decrease of leukocytes rolling, adhesion and migration to inflamed tissue $[56,57]$. In addition, ADO can also increase vasodilation and may inhibit platelet aggregation [58, 59], modifications that may well assist ticks while they feed.

Tick saliva also impairs the differentiation and biological activity of DCs by reducing their stimulatory and co-stimulatory molecules in vitro, and this was associated to ADO [26-29] and other molecules, such as Salp 15 and Japanin [25]. Moreover, others have shown that the A2b receptor is the mediator of ADO effects on DCs, which results in impaired maturation (reduced expression of MHCII and CD86) and immunogenicity of DCs $[35,60]$. Our data demonstrate that blocking ADO's receptors (8-pSPT-treated mice) can increase the percentage of DCs, as also as their activation state (augmented expression of CD40, CD80 and MHCII). It seems that compromising the initial steps of the immune response to inhibit the differentiation and maturation of DCs into functional antigen-presenting cells can impair tick rejection by the host.

Besides being a non-selective blocker of adenosine receptors, 8-pSPT (theophylline) also presents a 

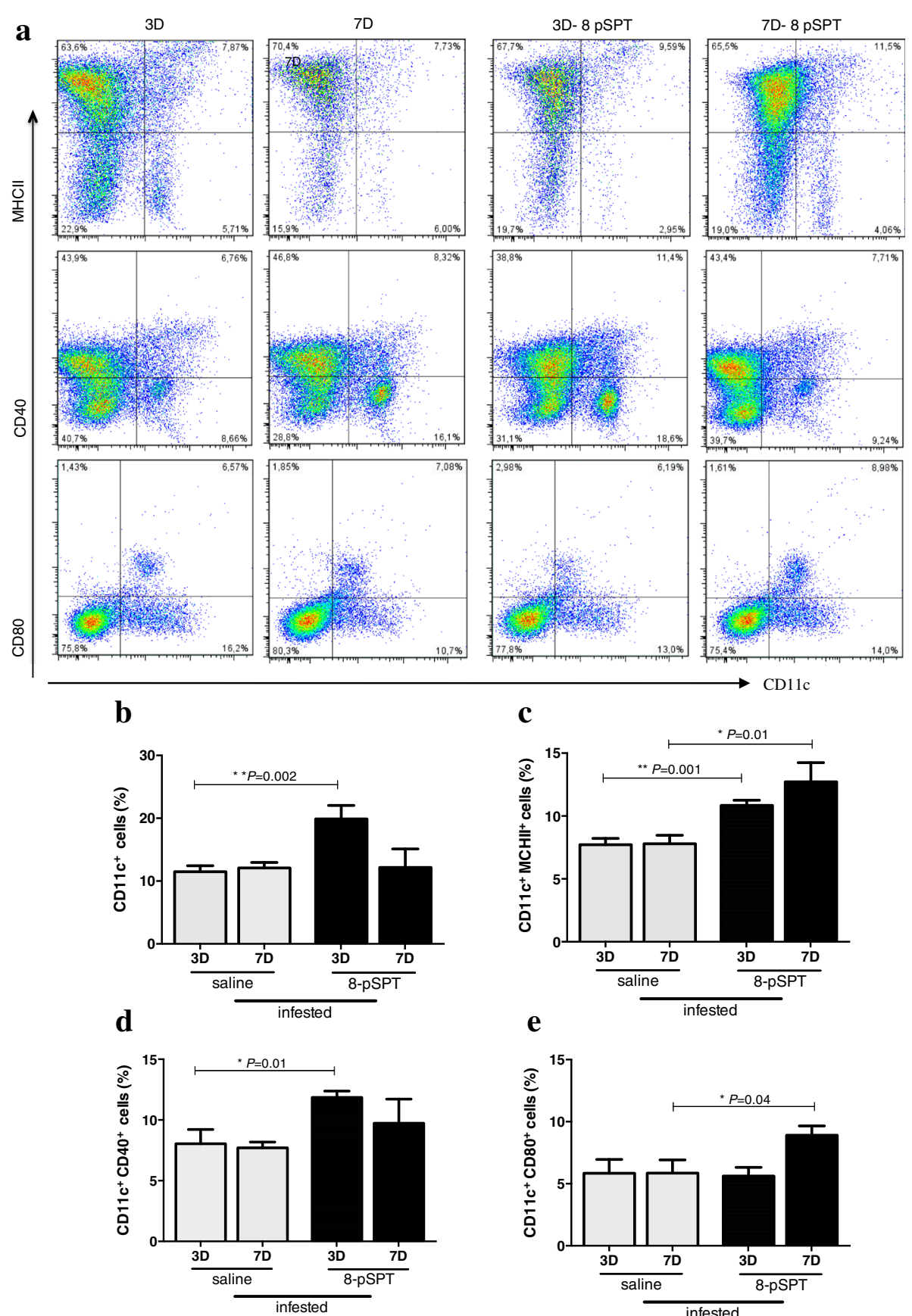

Fig. 3 DCs activation after treatment with ADO receptor antagonist in mice infested with ticks. BALB/c mice $(n=6 /$ group) were three times tickinfested and treated daily, throughout all infestations with a non-selective antagonist of ADO (8-pSPT, $20 \mathrm{mg} / \mathrm{kg}$ ip) or saline. Mice were killed on the 3rd and 7th day (3D and 7D) of the third infestation and their lymph nodes were harvested. Cells were labelled with the indicated antibody and analysed by flow cytometry. Data shown in $\mathbf{a}, \mathbf{b}, \mathbf{c}, \mathbf{d}$ and $\mathbf{e}$ are presented as the mean percentage of CD11c + cells expressing CD80, CD40 or MHCII \pm SEM from two independent experiments

phosphodiesterase (PDE) inhibitor activity [61]. The effect of selective inhibition of PDE4 (the main PDE expressed in immune cells) includes reduced secretion of IL-12 and TNF- $\alpha$ by DCs and impaired capacity to promote Th1-polarized responses [62, 63]. Impaired secretion of IL-12 and TNF- $\alpha$ by DC was observed in our work after 8-pSPT treatment, what could suggest some influence of PDE inhibition, even though theophylline is considered a weak inhibitor of PDE4, compared with its inhibitory activity on A1 and A2 ADO receptors [64]. However, we also observed a decreased production of IL-10 by DCs, 


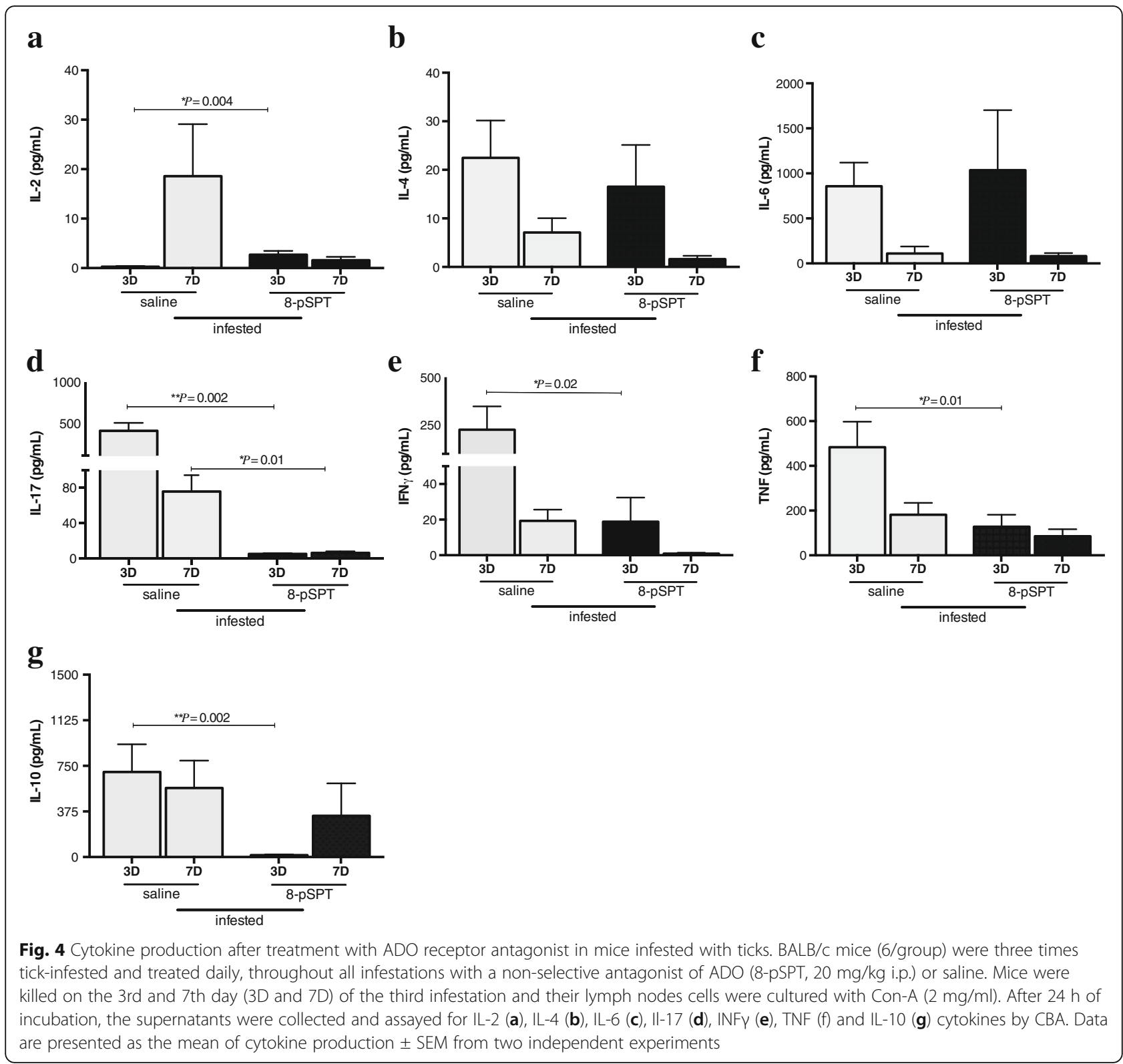

contrasting with the already described enhancement of IL-10 secretion by immune cells when PDE4 is inhibited [65]. Indeed, the increase of IL-10 is seen when DCs are stimulated with the non-selective ADO agonist NECA [35] and during tick infestations [66], while the treatment of DCs with a selective antagonist of the $\mathrm{A} 2 \mathrm{~B}$ receptor (which is upregulated during tick infestation, Fig. 4) impairs IL10 production [35]. In addition, PDE4 selective inhibition did not promote up-regulation of surface expression of HLA-DR, CD40 and CD80 like was observed when DCs were cultured in the presence of a non-selective agonist of ADO receptors NECA [35], corroborating our reasoning. Broadly, the DC phenotype promoted by PDE4 inhibition is similar to the phenotype presented during tick saliva's stimulus and is related with mice susceptibility to ticks, and not resistance, as shown in our work, what strongly suggests that our results are more to be due to ADO signalling than PDE signalling.

We have previously shown that ADO from tick saliva modulates cytokine production, downregulating IL12 p40 and TNF- $\alpha$, and upregulating IL-10 production by DCs [29]. In line with this report, it has been shown that ADO from human and mice impairs TNF- $\alpha$, IL-6, and IL-12 production, while it augments secretion of IL10 by DCs and macrophages [67-69]. Here we have shown that the ADO receptors blockade can revert the modulation by tick saliva. In this way, tick-infested mice treated with 8-pSPT induced a mixed cytokine profile, 
with a decrease of TNF, IFN- $\gamma$, IL-10 and IL-17 and increased of IL-2 production. The reduction of IL-17 is in line with other studies that show that, in autoimmune diseases models, the blockade of $\mathrm{A} 2 \mathrm{~b}$ receptors diminishes Th17 type cytokines [70]. On the other hand, the A2b receptor has also been shown to modulate the IL-6 production [71], a phenomenon that was not seen in this study.

Others have shown that ADO, per se, also inhibits $\mathrm{T}$ cell proliferation and reduces the synthesis of IL-2 $[36,56,72,73]$, while can increase the numbers of $\mathrm{T}$ regulatory cells through an increase in IL-10 at the inflamed site, which can inhibit the activity of effector $\mathrm{T}$ cells [74]. Moreover, the inhibition of $\mathrm{T}$ cell proliferation by $\mathrm{ADO}$ has been shown to occur via activation of the A2b receptor [75, 76]. Related to the role of A3 receptors in inflammation there is still a controversial debate. Some studies found that A3 receptor activation can improve inflammatory mediators release and degranulation in mast cells, suggesting a pro-inflammatory role [77, 78]. Other works have shown that its activation can suppress TNF- $\alpha$ release from LPS-stimulated macrophages and superoxide production and chemotaxis of neutrophils besides its competence to suppress the proliferation $\mathrm{T}$ cells [34, 78-81]. Interestingly, a recent study indicates a common association of the A3 receptor with potent analgesic effect in rodent models of chronic pain [82]. Maybe tick saliva's ADO signs via A3 receptor in the early phase of feeding, so it can get its blood meal properly by blocking pain.

\section{Conclusion}

Taken together, the results demonstrate that ADO, previously identified in the saliva of ticks, can bind to A2b and A3 receptors on host cells. As doing so, it inhibits the function of diverse cells of the host immune response, including dendritic and T cells, modulating both the innate immune response and the acquired immune response, inducing a mixed $\mathrm{T}$ cell type response that facilitates tick-feeding and reproduction.

\section{Abbreviations}

8-pSPT: 8-(p-Sulfophenyl)theophylline; A2aR-/-: Deficiency of the A2a receptor; ADO: Adenosine; Con-A: Concanavalin A; DCs: Dendritic cells; I-A/IE: MHCll; KO: Knockout; PGE2: Prostaglandin E2; WT: Wild-type

\section{Acknowledgements}

The authors thank Angélica Silva for technical assistance.

\section{Funding}

This work was supported by the Conselho Nacional de Desenvolvimento Científico e Tecnológico (CNPq), fellowship numbers 301,663/2007-6, 308,815/2010-6 and 308,280/2013-0 and São Paulo Research Foundation (FAPESP) grant agreement number 2011/00905-8 and fellowship number 2010/11285-8. The funders had no role in study design, data collection and analysis, decision to publish or preparation of the paper.

\section{Authors' contributions}

Conceived and designed the experiments: EA, CJFO and BRF. Performed the experiments: EA, CJFO, CMM, AF and NTBO. Analysed the data: EA, BRF and AF. Contributed reagents/materials/analysis tools: BRF, JSS and IKFMS. Wrote the paper: EA, BRF and AF. All authors read and approved the final manuscript.

\section{Competing interests}

The authors declare that they have no competing interests.

\section{Consent for publication}

Not applicable.

\section{Ethics approval}

The animal protocol was approved by Ethic Committee for the Use of Animals of the School of Medicine, University of São Paulo (project number 144/2010).

\section{Publisher's Note}

Springer Nature remains neutral with regard to jurisdictional claims in published maps and institutional affiliations.

\section{Author details}

${ }^{1}$ Institute of Science and Technology, Federal University of São Paulo, UNIFESP, Rua Talim, 330, São José dos Campos, São Paulo 12231-280, Brazil. ${ }^{2}$ Institute of Biological and Natural Sciences, Federal University of Triângulo Mineiro, UFTM, Praça Manoel Terra, 330, Uberaba, Minas Gerais 38015-050, Brazil. ${ }^{3}$ Department of Maternal and Child and Public Health Nursing, Ribeirão Preto School of Nursing, University of São Paulo, USP, Avenida Bandeirantes, 3900 Ribeirão Preto, São Paulo 14040-902, Brazil. ${ }^{4}$ Department of Biochemistry and Immunology, Ribeirão Preto School of Medicine, University of São Paulo, USP, Avenida Bandeirantes, 3900 Ribeirão Preto, São Paulo 14049-900, Brazil.

Received: 28 January 2017 Accepted: 15 June 2017

Published online: 10 July 2017

References

1. Pegram RG, Walker JB, Clifford CM, Keirans JE. Classification of the Rhipicephalus sanguineus group (Acari: Ixodoidea, Ixodidae). Syst Parasitol. 1987;10:3-26.

2. Dantas-Torres F. Canine vector-borne diseases in Brazil. Parasit Vectors 2008; : 25.

3. Jongejan F, Uilenberg G. The global importance of ticks. Parasitology. 2004; 129:3-14.

4. Almazán C, González-Álvarz V, Fernández de Mera I, Cabezas-Cruz A, Rodríguez-Martínez $\mathrm{R}$, de la Fuente J. Molecular identification and characterization of Anaplasma platys and Ehrlichia canis in dogs in Mexico. Ticks Tick Borne Dis. 2016;7:276-83.

5. Cupp EW. Biology of ticks. Vet Clin North Am Small Anim Pract. 1991;21:1-26.

6. Dantas-Torres F, Figueredo L, Brandão-Filho S. Rhipicephalus sanguineus (Acari: Ixodidae), the brown dog tick, parasitizing humans in Brazil. Rev Soc Bras Med Trop. 2006;39:64-7.

7. Dantas-Torres F. Biology and ecology of the brown dog tick, Rhipicephalus sanguineus. Parasit Vectors. 2010;3:26.

8. Demma LJ, Holman RC, McQuiston JH, Krebs JW, Swerdlow DL. Epidemiology of human ehrlichiosis and anaplasmosis in the United States, 2001-2002. Am J Trop Med Hyg. 2005;73:400-9.

9. Ribeiro JM. Role of saliva in tick/host interactions. Exp Appl Acarol. 1989;7:15-20.

10. Ribeiro $\mathrm{JM}$, Francischetti IM. Role of arthropod saliva in blood feeding: sialome and post-sialome perspectives. Annu Rev Entomol. 2003;48:73-88,

11. Francischetti IM, Sa-Nunes A, Mans BJ, Santos IM, Ribeiro JM. The role of saliva in tick feeding. Front Biosci. 2009;14:2051-88.

12. Kovar L. Tick saliva in anti-tick immunity and pathogen transmission. Folia Microbiol (Praha). 2004;49:327-36.

13. Wikel SK. Host immunity to ticks. Annu Rev Entomol. 1996;41:1-22.

14. Mans BJ. Tick histamine-binding proteins and related lipocalins: potential as therapeutic agents. Curr Opin Investig Drugs. 2005;6:1131-5.

15. Ribeiro JM. Blood-feeding arthropods: live syringes or invertebrate pharmacologists? Infect Agents Dis. 1995;4:143-52. 
16. Anatriello E, Ribeiro JM, de Miranda-Santos IK, Brandao LG, Anderson JM, Valenzuela JG, et al. An insight into the sialotranscriptome of the brown dog tick, Rhipicephalus sanguineus. BMC Genomics. 2010;11:450.

17. Steen NA, Barker S, Alewood P. Proteins in the saliva of the Ixodida (ticks): pharmacological features and biological significance. Toxicon. 2006;47:1-20.

18. Ribeiro JM, Makoul GT, Levine J, Robinson DR, Spielman A. Antihemostatic, antiinflammatory, and immunosuppressive properties of the saliva of a tick, Ixodes dammini. J Exp Med. 1985;161:332-44.

19. Francischetti IM. Platelet aggregation inhibitors from hematophagous animals. Toxicon. 2010;56:1130-44.

20. Urioste S, Hall L, Telford S, Titus R. Saliva of the Lyme disease vector, Ixodes dammini, blocks cell activation by a nonprostaglandin E2-dependent mechanism. J Exp Med. 1994;180:1077-85.

21. Ferreira BR, Silva JS. Saliva of $R$. sanguineus tick impairs $T$ cell proliferation and IFN-g-induced macrophage microbicidal activity. Vet Immunol Immunopathol. 1998;64:279-93.

22. Wikel SK. Tick modulation of host cytokines. Exp Parasitol. 1996;84:304-9.

23. Ramachandra RN, Wikel SK. Modulation of host immune responses by ticks (Acari: Ixodidae): effect of salivary gland extracts on host macrophages and lymphocyte cytokine production. J Med Entomol. 1992;29:818-26.

24. Kopecky J, Kuthejlová M. Suppressive effect of Ixodes ricinus salivary gland extract on mechanisms of natural immunity in vitro. Parasite Immunol. 1998; 20:169-74.

25. Preston SG, Majtán J, Kouremenou C, Rysnik O, Burger LF, Cabezas Cruz A, et al. Novel immunomodulators from hard ticks selectively reprogramme human dendritic cell responses. PLoS Pathog. 2013;9:e1003450.

26. Cavassani K, Aliberti J, Dias A, Silva J, Ferreira BR. Tick saliva inhibits differentiation, maturation and function of murine bone-marrow-derived dendritic cells. Immunology. 2005;114:235-45.

27. Oliveira C, Cavassani K, Moré D, Garlet G, Aliberti J, Silva JS, et al. Tick saliva inhibits the chemotactic function of MIP-1alpha and selectively impairs chemotaxis of immature dendritic cells by down-regulating cell-surface CCR5. Int J Parasitol. 2008;38:705-16.

28. Oliveira CJ, Carvalho WA, Garcia GR, Gutierrez FR, de Miranda Santos IK, Silva JS, et al. Tick saliva induces regulatory dendritic cells: MAP-kinases and toll-like receptor-2 expression as potential targets. Vet Parasitol. 2010;167:288-97.

29. Oliveira C, Sá-Nunes A, Francischetti I, Carregaro V, Anatriello E, Silva JS, et al. Deconstructing tick saliva: non-protein molecules with potent immunomodulatory properties. J Biol Chem. 2011;286:10960-9.

30. Ribeiro JM, Weiss JJ, Telford SR. Saliva of the tick Ixodes dammini inhibits neutrophil function. Exp Parasitol. 1990;70:382-8.

31. Ribeiro JM, Spielman A. Ixodes dammini: salivary anaphylatoxin inactivating activity. Exp Parasitol. 1986;62:292-7

32. Rescigno M. Dendritic cells and the complexity of microbial infection. Trends Microbiol. 2002;10:425-61.

33. Blackburn MR, Vance $C$, Morschl E, Wilson C. Adenosine receptors and inflammation. Handb Exp Pharmacol. 2009;193:215-69.

34. Borea P, Varani K, Vincenzi F, Baraldi $P$, Tabrizi $M$, et al. The $A 3$ adenosine receptor: history and perspectives. Pharmacol Rev. 2015;67:74-102.

35. Novitskiy S, Ryzhov S, Zaynagetdinov R, Goldstein A, Huang Y, Tikhomirov OY, et al. Adenosine receptors in regulation of dendritic cell differentiation and function. Blood. 2008;112:1822-31.

36. Cheong S, Federico S, Venkatesan G, Mandel A, Shao Y, Moro S, et al. The A3 adenosine receptor as multifaceted therapeutic target: pharmacology, medicinal chemistry, and in silico approaches. Med Res Rev. 2013;33:235-5.

37. Ryzhov S, Zaynagetdinov R, Goldstein A, Novitskiy S, Blackburn M, Biaggioni I, et al. Effect of A2B adenosine receptor gene ablation on adenosinedependent regulation of proinflammatory cytokines. J Pharmacol Exp Ther. 2008;324:694-700

38. Ohta A, Sitkovsky M. Role of G-protein-coupled adenosine receptors in downregulation of inflammation and protection from tissue damage. Nature. 2001:414:916-20.

39. Lukashev D, Ohta A, Apasov S, Chen J, Sitkovsky M. Cutting edge, physiologic attenuation of proinflammatory transcription by the Gs proteincoupled A2A adenosine receptor in vivo. J Immunol. 2004;173:21-4.

40. Ribeiro J, Modi G. The salivary adenosine/AMP content of Phlebotomus argentipes Annandale and Brunetti, the main vector of human kala-azar. J Parasitol. 2001:87:915-7.

41. Kato $H$, Jochim $R$, Lawyer $P$, Valenzuela J. Identification and characterization of a salivary adenosine deaminase from the sand fly Phlebotomus duboscai, the vector of Leishmania major in sub-Saharan Africa. J Exp Biol. 2007;210:733-40.
42. Carregaro V, Ribeiro J, Valenzuela J, Souza-Júnior D, Costa D, Oliveira CJ, et al. Nucleosides present on phlebotomine saliva induce immunossuppression and promote the infection establishment. PLoS Negl Trop Dis. 2015;9:e0003600.

43. Bechara GH, Szabó MP, Machado RZ, Rocha UF. Technique for collecting saliva from the cattle-tick Boophilus microplus (Canestrini, 1887) using a chemical stimulation. Enviromental and temporal influences on secretion yield. Braz J Med Biol Res. 1988;21:479-84.

44. Chen J, Huang Z, Ma J, Zhu J, Moratalla R, Standaert D, et al. A(2A) adenosine receptor deficiency attenuates brain injury induced by transient focal ischemia in mice. J Neurosci. 1999;19:9192-200.

45. Blackburn MR, Vance CO, Morschl E, Wilson CN. Adenosine receptors and inflammation. Handb Exp Pharmacol. 2009;193:215-69.

46. Hume ME, Essenberg R, McNew RW, Bantle JA, Sauer JR. Adenosine-3',5'monophosphate in salivary glands of unfed and feeding female lone star ticks, Amblyomma americanum (L.). Comp Biochem Physiol C. 1984;79:47-50.

47. Poole NM, Mamidanna G, Smith RA, Coons LB, Cole JA. Prostaglandin E(2) in tick saliva regulates macrophage cell migration and cytokine profile. Parasit Vectors. 2013;6:261.

48. Murphree $L$, Sullivan GW, Marshall MA, Linden J. Lipopolysaccharide rapidly modifies adenosine receptor transcripts in murine and human macrophages: role of NF-kappaB in a $(2 \mathrm{~A})$ adenosine receptor induction. Biochem J. 2005;1:575-80.

49. Federico S, Spalluto $G$. Therapeutic potential of $A 2$ and $A 3$ adenosine receptor: a review of novel patented ligands. Expert Opin Ther Pat. 2012:22:369-90.

50. Koupenova M, Ravid K. Adenosine, adenosine receptors and their role in glucose homeostasis and in glucose homeostasis and lipid metabolism. J Cell Physiol. 2013;

51. Yang D, Koupenova M, McCrann D, Kopeikina K, Kagan H, Schreiber BM, et al. The A2b adenosine receptor protects against vascular injury. Proc Ntnl Acad Sci USA. 2008;105:792-6.

52. Kong T, Westerman K, Faigle M, Eltzschig H, Colgan S. HIF-dependent induction of adenosine A2B receptor in hypoxia. FASEB J. 2006;20:2242-50.

53. Lee JL, Mukthar H, Bickers DR, Kopelovich L, Aathar M. Cyclooxygenases in the skin: pharmacological and toxicological implications. Toxicol Appl Pharmacol. 2003;192:294-306.

54. Kotál J, Langhansová H, Lieskovská J, Andersen J, Francischetti I, Chavakis T, et al. Modulation of host immunity by tick saliva. J Proteome. 2015;128:58-68.

55. Kotsyfakis M, Schwarz A, Erhart J, Ribeiro J. Tissue- and time-dependent transcription in Ixodes ricinus salivary glands and midguts when blood feeding on the vertebrate host. Sci Rep. 2015;5:9103.

56. Linden J, Cekic C. Regulation of lymphocyte function by adenosine. Arterioscler Thromb Vasc Biol. 2012:9:2097-103.

57. Johnston A, Gudjonsson J, Sigmundsdottir H, Ludviksson B, Valdimarsson $\mathrm{H}$. The anti-inflammatory action of methotrexate is not mediated by lymphocyte apoptosis, but by the suppression of activation and adhesion molecules. Clin Immunol. 2005;114:154-63.

58. Collis M. The vasodilator role of adenosine. Pharmacol Ther. 1989;41:143-62.

59. Haslam RJ, Davidson MM, Davies T, Lynham JA, McClenaghan MD. Regulation of blood platelet function by cyclic nucleotides. Adv Cyclic Nucleotide Res. 1978;9:533-52.

60. Wilson J, Ross W, Agbai O, Frazier R, Figler R, Rieger J, et al. The A2B adenosine receptor impairs the maturation and immunogenicity of dendritic cells. Handb Exp Pharmacol Rev. 2009;193:329-62.

61. Ukena D, Schudt C, Sybrecht GW. Adenosine receptor-blocking xanthines as inhibitors of phosphodiesterase isozymes. Biochem Pharmacol. 1993;45:847-51.1.

62. Hertz AL, Beavo JA. Cyclic nucleotides and phosphodiesterases in monocytic differentiation. Handb Exp Pharmacol. 2011;204:365-90.

63. Heystek H, Thierry A, Soulard P, Moulon C. Phosphodiesterase 4 inhibitors reduce human dendritic cell inflammatory cytokine production and Th1polarizing capacity. Int Immunol. 2003;15:827-35.

64. Ukena D, Schudt C, Sybrecht GW. Adenosine receptor-blocking xanthines as inhibitors of phosphodiesterase isozymes. Biochem Pharmacol. 1993;45: 847-51.

65. Boswell-Smith V, Cazzola M, Page CP. Are phosphodiesterase 4 inhibitors just more theophylline? J Allery Clin Immunol. 2006;117:1237-43.

66. Ferreira BR, Silva JS. Successive tick infestations selectively promote a Thelper 2 cytokine profile in mice. Immunology. 1999:96:434-9.

67. Hasko G, Kuhel D, Chen J, Schwarzschild M, Deitch E, Mabley JG, et al. Adenosine inhibits $\mathrm{LL}-12$ and TNF-a production via adenosine $\mathrm{A} 2 \mathrm{a}$ receptordependent and independent mechanisms. FASEB J. 2000;14:2065-74. 
68. Csoka B, Nemeth Z, Virag L, Gergely P, Leibovich S, Pacher P, et al. A2A adenosine receptors and C/EBPbeta are crucially required for IL-10 production by macrophages exposed to Escherichia coli. Blood. 2007; 110:2685-95.

69. Panther E, Corinti S, Idzko M, Herouy Y, Napp M, la Sala A, et al. Adenosine affects expression of membrane molecules, cytokine and chemokine release, and the T-cell stimulatory capacity of human dendritic cells. Blood. 2003;101:3985-90.

70. Chen M, Liang D, Zuo A, Shao H, Kaplan H, Sun D. An A2b adenosine receptor agonist promotes Th17 autoimmune responses in experimental autoimmune uveitis (EAU) via dendritic cell activation. PLoS One. 2015; 10:e0132348.

71. Figler R, Wang G, Srinivasan S, Jung D, Zhang Z, Pankow JS, et al. Links between insulin resistance, adenosine A2B receptors, and inflammatory markers in mice and humans. Diabetes. 2011;2:669-79.

72. Huang S, Apasov S, Koshiba M, Sitkovsky M. Role of A2a extracellular adenosine receptor-mediated signaling in adenosine-mediated inhibition of T-cell activation and expansion. Blood. 1997;90:1600-10.

73. Butler J, Mader J, Watson C, Zhang H, Blay J, Hoskin DW. Adenosine inhibits activation-induced T cell expression of CD2 and CD28 co- stimulatory moleculces: role of interleukin-2 and cyclic AMP signaling pathways. J Cell Biochem. 2003:89:975-91.

74. Whiteside T, Mandapathil M, Schuler P. The role of the adenosinergic pathway in immunosuppression mediated by human regulatory $T$ cells (Treg). Curr Med Chem Rev. 2011;18:5217-23.

75. Dubey R, Gillespie D, Shue H, Jackson E. A(2B) receptors mediate antimitogenesis in vascular smooth muscle cells. Hypertension. 2000;35:267-72.

76. Dubey R, Gillespie D, Mi Z, Jackson E. Adenosine inhibits PDGF-induced growth of human glomerular mesangial cells via a(2B) receptors. Hypertension. 2005;46:628-34.

77. Ramkumar V, Stiles GL, Beaven MA, Ali H. The A3 adenosine receptor is the unique adenosine receptor which facilitates release of allergic mediators in mast cells. J Biol Chem. 1993;268:16887-90.

78. Salvatore C, Tilley S, Latour A, Fletcher D, Koller B, Jacobson MA. Disruption of the $\mathrm{A} 3$ adenosine receptor gene in mice and its effect on stimulated inflammatory cells. J Biol Chem. 2000;275:4429-34.

79. Van Der Hoeven D, Wan TC, Auchampach JA. Activation of the A3 adenosine receptor suppresses superoxide production and chemotaxis of mouse bone marrow neutrophils. Mol Pharmacol. 2008;74:685-96.

80. Martin L, Pingle S, Hallam D, Rybak L, Ramkumar V. Activation of the adenosine A3 receptor in RAW 264.7 cells inhibits lipopolysaccharidestimulated tumor necrosis factor-alpha release by reducing calciumdependent activation of nuclear factor-B and extracellular signal regulated kinase 1/2. J Pharmacol Exp Ther. 2006:318:71-8.

81. Fishman P, Bar-Yehuda S, Synowitz M, Powell JD, Klotz K, Gessi S, et al. Adenosine receptors and cancer. Handb Exp Pharmacol. 2009;193:399-441.

82. Ford A, Castonguay A, Cottet M, Little J, Chen Z, Symons-Liguori AM, et al. Engagement of the GABA to KCC2 signaling pathway contributes to the analgesic effects of A3AR agonists in neuropathic pain. J Neurosci. 2015:35:6057-67.

\section{Submit your next manuscript to BioMed Central and we will help you at every step:}

- We accept pre-submission inquiries

- Our selector tool helps you to find the most relevant journal

- We provide round the clock customer support

- Convenient online submission

- Thorough peer review

- Inclusion in PubMed and all major indexing services

- Maximum visibility for your research

Submit your manuscript at www.biomedcentral.com/submit
Biomed Central 